\title{
The Influence Analysis of Green Economy on the Development of Majors under Economics and Management in Vocational Colleges in China
}

\author{
Kai Liu, ${ }^{1, *}$ Wen Zhou ${ }^{1}$ and Boru Yang ${ }^{1}$ \\ ('Yunnan College of Foreign Affairs \& Foreign Language, YunnanKunming 651700 China) \\ *The Corresponding author
}

\begin{abstract}
Keywords: Green Economy; Vocational Colleges; Economics And Management; Influence Analysis
\end{abstract}

\begin{abstract}
As the mainstream model of world economy development, green economy has always advocated green and management concepts throughout the process of economy development in our country. In the meantime, in order to speed up the reality of green development that realizes the long-term plan for promoting social employment and solving livelihood problems, the Central Government actively advocates developing modern vocational education. A series of measures that vigorously develop vocational education, earnestly turn economic growth onto scientific and technological progress, improve educational level of workers, and analyze influences of green economy will provide references for the development of majors under Economics and Management in vocational colleges in our country.
\end{abstract}

\section{The Status Quo of Green Economy Development in China}

"Green Economy" was first proposed by British economist Pierce in Blue Book of Green Economy published in 1989, which is one of the most dynamic and promising economy forms in the $21 \mathrm{st}$ century. Green economy is a form that is market-oriented, based on traditional industrial economy and developed for the purpose of economic and environmental harmony. Also, it is a state of development that industrial economy has produced and demonstrated in the sake of human environmental protection and health. In short, it is a low-carbon, an environmentally friendly and a renewable economy. The focus of China's green economy development is to achieve green growth by greening industrial structure and developing green booming industries. "Proposal of the Central Committee of the Communist Party of China on formulating the $13^{\text {th }}$ Five-Year Plan for National Economic and Social Development" adopted by the Fifth Plenary Session of the $18^{\text {th }}$ Central Committee of the Communist Party of China combined "Greenness" with "Innovation, Coordination, Opening up and Sharing" as "Development Concepts". As one of the major development concepts and goals, green economy runs through all aspects of economic and social development in the " $13^{\text {th }}$ Five-Year Plan". What's more, during important transition period for China's economy development momentum, green economy is expected to become a new impetus to promote sustained economic growth and upgrade.

Vocational and technical education center of Ministry of education had successfully applied for the project of APEC, which is use environmental way and skill to develop the vocational education in 2014. This is the first time that China has successfully applied for a vocational education project from APEC since 21 century. The purpose of this project is to combine the idea of green, environment friendly and sustainable development with the vocational system together, meanwhile it also could train environmental skilled talents and most importantly it could stimulate the economy and society development of the area on APEC. Some idea had been presented such as the basic connotation of green skills, the catalog of the development of some typical areas in Asian, how to build the network of green skill on Asian areas. The project also had set up a comprehensive reach group and a special reach group; they included 11 specialties which are Agriculture, energy, meteorological environmental protection, construction, manufacturing, logistics, petrochemical, computer, e-commerce, medicine and tourism.

Some topics have been mentioned clearly in the National medium - and long-term plan for education reform and development outlines(2010-2020), such as accelerate the development of 
modern professional education, improve the training vocational skills, how to increase employment and entrepreneurship of workers. These topics indicated that vocational educations have been playing a great role on the adjustment of industrial structures and economic and social transformation. So we should put vocational educations as our top priorities and also put some proper adjustments to adapt the development of economy.

\section{The Analysis of how the Green Economy Affects the Development of Majors in Economic Management on Vocational Colleges in China}

\section{From School Level}

Pay attention to the construction of college environmental sanitation

College sanitation works are the indispensable parts of college educations. The improvement of environmental and hygiene on college plays a great role to facilitate the intelligence, physique and health of the students. Therefore we must improve and attach importance to the college environmental and hygiene works. Only by these ways the college environmental and hygiene works can be continued normally, the students' health status can be improved gradually. According to our reaches only some of the vocational college students were satisfied with their school environments. Therefore, college should focus more on the development of the environmental and sanitation constructions. Only to let the college to build a clean and hygiene environment, students can focus on the studying and teachers can teach better. So we must to keep the hygiene and the environment of the college, only by this way could we make students learn more and keep a good atmosphere for us and also can better display the image of the school itself.

Strengthen Campus Green Infrastructure Construction

Green Infrastructure (GI) is a concept different from gray infrastructure which is including road, sewers and other utilities, or social infrastructure which is including schools, hospitals and prisons. To strengthen school green infrastructure construction can be a guidance to develop the ecology, society and diversified green campus. Specifically speaking, it is needed to, firstly strengthen the construction of the green campus network structure system and to focus on the optimization of the green space patterns in the campus area; secondly enhance the treatment of solid waste and garbage, the library collection construction of increasing books about environment and resources protection, and improve the construction of campus green infrastructure.

Strengthen the Construction of Green University

Above all, it is needed to strengthen the idea of green higher education, to evaluate all work using the concept of sustainable development and to speed up to establish a teaching and management team with the idea of sustainable development and green economy. Next, it is needed to focus on the content of green education. Firstly, teaching planning should be completed. It is needed to emphasis on achieving the cultivating aim of green economy knowledge, skills and abilities, and the attitude and value in teaching planning process. Secondly, subjects relate to sustainable development and environment protection should be set up combining with the school-running feature. Thirdly, the curriculum arrangement should be improved. It is needed to immersion the concept of environment protection and green economy in various subjects and major courses teaching process combining the required and optional courses together. Fourthly, topic education should be emphasized. Universities should usually or regularly hold special lecture or seminar about environment education and green economy according to the actual condition. Fifthly, the teaching technology should be upgraded. By adopting a new teaching management pattern and using green teaching technology and green product, to enhance the teaching efficiency, and to reduce teaching cost, environment pollution and educational resources in the process of teaching.

\section{On Enterprise Level}

Emphasis on Green Talents Introduction

Emphasis on the introduction of green talents to enrich employees' internal structure. First, pay attention to the introduction of high-quality green personnel. The enterprise should focus on the introduction of the green youth talents, excellent green entrepreneurs and overseas high-level talents, professional and technical personnel, enhance the modernization management level and 
international competitiveness and enrich employees structure of the environment-friendly enterprise; secondly, the environment-friendly enterprise salary system should be improved, the mode of employee shareholding should be actively adopted to realize the mutual appreciation of green talent capital and the enterprise business capital. At the same time, the salary of green talents should be linked to education, job title, skill level to set up a job and performance oriented salary system to attract talents; thirdly, it is needed to perfect the green talent career development to provide a good promotion mechanism, and to implement the talents incentive system that all excellent talent in each position in the tourism industry who puts forward a rationalization proposal or whom with inventions, valuable technological innovation or research papers should be rewarded every year.

To strengthen the cultivation of green talents

We should strengthen the external training of green talents, and build up the continuing education system for tourism professionals with tiered classification. We can set up commissioned training of qualified university and institutes to train a group of practical tourism talents, such as encouraging talents to have or set up the master of tourism management (MTA) education. We should perfect the talent training mechanism of tourism, enterprise and management comprised by government, training institutions and employers as a trinity unit, and build tourism professional managers training platform. Secondly, we should strengthen the internal training of green talents, and cultivate enterprise's own tourism professional lecturer or hire experts and scholars to improve continuing education for green talents with various internal training systems. Thirdly, to encourage existing talent to improve the development of tourism, the ability of management and service through the exchange of learning, secondment for getting experience and practice on the basis of reinforced green talents training for enterprise.

To improve the employment mechanism of enterprises

We will improve the employment mechanism of enterprises and retain talents in the tourism industry. And we should guide the tourism enterprises to optimize human resources management mechanism, talent resources allocation, development mechanism, and encourage enterprise to actively increase investment in talent development and innovate green talent development mechanism. In addition, we will build a consulting platform for talent development of enterprises, and support tourism enterprises to improve their talent development mechanism.

Secondly, we establish the appraisal system for human resource development of tourism enterprise, and strengthen the cooperation between tourism enterprises and tourism institutions, innovating tourism enterprises and universities in the practice of the degree of integration, and enrich the form and content of the cooperation. Thirdly, increase the content and dimension of green talent performance appraisal. Existing evaluation system that performance enhancement as the main evaluation index not only covers the previous administrative management, tour guide and the leader of tourism and top management but also add evaluation of other related professionals to increase the formation of systematic management, earnestly implement the responsibility system.

\section{Individual Levels}

Enhance individual green awareness

First, we can use a variety of means to carry on green environment education in daily life. For example, in life, we insist on water saving, electricity saving, no plastic shopping bags, no disposable chopsticks, etc. To learn the environmental protection signs of commodities, buy green environmental products, and make the green ideas into action. Secondly, improving the students' awareness of green through the school education, which has profound meanings for the sustainable development of the country and the construction of green university .therefore, setting up green courses, implementing class activities for world environment day, water saving, and lights out for an hour for according to the development of society and school to further enhance the green environmental consciousness of the students. Finally, we improve individual green engagement, to strengthen the green consciousness of people through Arbor Day, no tobacco day, and world environment day to improve the citizens' understanding in the environmental management. So we can further improve the environmental participation of citizens.

Individual career planning 
Career planning is analyzed and measured against the decision of individual career choices of subjective and objective factors that determine personal goals and career goals, and his career the process of rational planning. The graduates in our survey are not very clear about their three to five years of study and work plan, and career planning helps to choose their career paths: Occupational anchors formed through the accumulation of work experience reflect not only individual values and talents, but also the potential needs and motivations of individuals entering adulthood. One cast "anchored" to a particular course of professional work, in fact, true knowledge of the process of individual self, to know themselves what kind of ability, competence, and to find their own contribution to long-term stable employment area, to determine their own future career choice.

\section{Conclusion}

In the context of the green economy booming, the development of vocational education put forward higher requirements, vocational education must be reformed in terms of training model, China's vocational education element green economy should be fully integrated into the curriculum to achieve The green development of vocational education provides strong intellectual support for the path of sustainable development. In the era of green economy, the development of schools, enterprises and individuals will all affect the cultivation of students' comprehensive vocational ability. Occupational education plays a decisive role in raising the level of labor skills, optimizing the allocation of labor resources and accelerating the conversion of science and technology into productive forces for the development of a green economy.

\section{Acknowledgement}

Construction of green talents cultivation mode for the economy and management specialty of higher vocational colleges2016ZZX349

\section{References}

[1] Wang Liji, Luo Guosheng. School-enterprise dual system personnel training model and evaluation system [M]. Jinan University press, March 2016

[2] Hu Changrong. Higher vocational school personnel training school-enterprise ability to increase education model [J]. Education and Careers, 2015 (11)

[3] Higher Education Branch of Higher Education Society of China, Southwest University of Finance and Economics, Higher Financial Education Research Center. Deepening Higher Financial Education Reform Innovative Talents Institutional Mechanism (Higher Financial Education Research 2014 Higher Education Forum) [C] .Southwest University of Finance Press, October 2015

[4] [12]Neville Bennett、Elisabeth Dunne、Clive Carre.Skills Development in Higher Education and Employment[M].Open University Press, June 2000

[5]Albert B. Hood.What Type of College for What Type of Student?[M].University of Minnesota Press, January 1965

\footnotetext{
About author:

*Kai Liu(1983-)Inner Mongolia root river city person, Associate professor, postgraduate, Assistant dean of foreign foreign language vocational college of yunnan, Mainly engaged in teaching management, 649601243@qq.com.

Wen Zhou(1974-) Chongqing people, Research assistant, postgraduate, Teacher of yunnan foreign language vocational college, Mainly engaged in ideological and political education,249773193@qq.ocm.

Boru Yang(1989-)female, Hebei Tang Shan, master graduate student, lecturer title, research direction: human resources management, organizational behavior, economics of education, $945211931 @$ qq.ocm.
} 